\title{
Forest Utilization Pattern of Local People: A Study of Sewar Bansbot Village of Dang
}

Dr.Ganga K.C.*

\begin{abstract}
This article explores the utilization pattern of forest products. Forest is one of the most important natural resources that have directly benefitted the rural people continuously. The people ofstudy area are dependent on forest for the essential elements of fodder, firewood and timber. The economic role of forests in human life is also valuable.The objectives of this article are to describe the forest utilization pattern and to find out how the local people consume the different forest products respectively as their needs.In the study area firewood is the principal source of energy for cooking and heating until now days.The consumption of firewood depends on the size of family member and utilization purpose.Fodder is very important for livestock raising.Leaves, green twigs and small plants are needed for livestock as their diet.Local people in the study area consume Sotar in order to obtain high volume of compost manure for agriculture. Some people deposit green leaves into the compost pit for decomposition, which is converted into the organic manure. And farmers use this manure in their crop fields according to the requirements.It is mainly depend on the livestock size and availability of the bedding materials in the surroundings. Cattle are strictly prohibited in the entire area of Ban to graze.
\end{abstract}

Keywords: Utilization, Animal bedding, Firewood, Fodder and Local people.

\section{Introduction}

Forests are valuable environmental and economic resources for supporting natural systems and for improving human welfare (Sharma, 1992).Human activities always change the forest environment, but in recent years the intensity and scale of the forest use have increased significantly. Everyone benefits from the forest until and unless people treat forests as renewable resources, protect them to preserve their bio-diversity or transform them to support other economic activities on a sustainable basis.Forest is one of the most important natural resources that have benefitted the people of Nepalese villages continuously from the very beginning, and people have been utilizing forest resources massively and persistently for their existence and sustain for their economic life.

\footnotetext{
* Dr.KC is an Associate Professor of Department Anthropology, T.U., Patan Multiple Campus, PatanDhoka.
} 
Conversely, destructive exploitation of forests can cause serious economic, social and environmental losses.

At the same time, there are strong differences of opinion among people, as well as among nations about how forests should be used and managed to support conservation and to achieve development goals while one group of people emphasize privatization of natural resources as the effective and efficient management whereas other emphasizes for nationalization. However, community forest has been one of the important ways of protecting forest resources in Nepal for last several decades.

Gilmour and Fisher (1991) opined that forest resources are one of the major resources directly contributing to the survival of rural people in Nepal. Forest resources directly fulfill forest related subsistence needs of women; poor and backward people as well as commercial needs of well-off people. Most of the rural people directly or indirectly depend on the forest for firewood, fodder, animal bedding, animal grazing, and timber and non-timber forest products. Not only these forests also support irrigation, conserve watersheds, improve the condition of the soil, provide recreation for tourists through forest based eco-tourism and national parks and wildlife reserves, provide a habitat for flora and fauna and provide raw materials for the forest based industries (Bhatia, 1999). Nepalese rural economy and subsistence especially depend on forest and agriculture. Agriculture is mainly based on forests. Rural people consume different types of forest products for the different purposes. People use the compost manure in the crop field for better yielding of grains. Rural people harvest green litter and fallen leaves for animal bedding and fodder for cattle from the forest and private land to make manure. Likewise rural people graze their livestock in common grazing land and forest.

The consumption pattern of different forest products especially firewood varies in different ecological regions. As Wallace (1988) mentioned that firewood consumption in the hilly regions is higher than that of the dwellers in the mountain and terai regions. Due to the lack of other alternative sources of energy for cooking and heating, most of the rural people depend on forest for firewood. According to economic Survey (1994), of the total energy sources $91 \%$ is acquired from the traditional sources. This data shows the high dependency of rural people on firewood. Likewise, Regmi (1992) mentioned that livestock farming in Nepal is also dependent on forest resources. The forest areas of Nepal produce more than 50 $\%$ of Nepal's total supply of animal foods in the hilly region. The other resources of fodder grass are available in domestic trees, shrub land, pasture and other grazing land. Agricultural residues and terraces also serve the animal food. 
Some studies have been done in different parts of Nepal about forest management system but very few studies have been made on the forest utilization pattern. This is a micro level analysis of issues on forest utilization pattern in the rural area. Despite such an importance, the existing local patterns of the forest use present a rather critical position in the village of Nepal. Therefore, in order to maintain sustainability in the use of natural resources, it has become an urgent need to study forest utilization patterns in rural areas of Nepal. This shows the research gap in the forest utilization pattern so the following research question are raised under this study.

- What is the forest utilization pattern in the study area?

- $\quad$ How do the peoples of the study area utilize the forest product in daily life?

\section{Objective}

The overall objective of this study is to describe the forest utilization pattern. And the specific objective is to explore how the local people consume the different forest products respectively as their needs.

\section{Method}

This study adopted exploratory and descriptive research design. For the study Sewar Bansbot village of Dang district was purposively selected.The fieldwork was carried out on 2017. This study makes an attempt to describe, explore and assemble the necessary data to document the forest utilization pattern. The emphasis of the study is on the qualitative rather than the quantitative aspect. Primary data was collected through interviews with key informants and local people. Structured interview schedule was used for the interview. There are 45 households in the study area. All the household heads were interviewed at the time of field study. Three persons have been selected as key informant. These three persons have been interviewed frequently on various issues related to forest utilization pattern.However necessary secondary data have been collected through documentary sources like published and unpublished sources.

\section{Use of the forest products}

Forest is one of the most important natural resources that have directly benefitted the rural people continuously for many years. People have been utilizing necessary forest products massively for their existence and continuity for their economic life. Forest has been providing various necessary materials.And forest is an integral part of the farming system. In the study area, there is heavy dependency on forest for the essential elements of fodder, firewood and timber. Forest provides firewood for cooking and heating, fodder for domestic 
animals nutrition. Fallen leaves are used for manufacturing organic manure and bedding for animals.

For this study Sewar, Bansbot village was purposively selected. Tharu, magar, Kshetri, Brahman and Kami are the main inhabitants of the area. Magar people of this area are migrants from Rolpa and Rukum.The forest area of Bansbot is divided into two parts: one lies in the western part of the village area under the protection and management of the local people which is known as Dahajharan and Niuresota Ban and another part which is known as Dhanchhare, Maulakot and Budhakot Ban in northern part of the study area, under the government and villager's control. The great contribution of the forest for the local people of Bansbot includes fuel wood, timber, seasonal fruits and vegetables. It also provides fodder and shelter for livestock and wild animals. The productivity of the land of study area also depends on these Ban (forest).The major species of these Ban (forest)are Sal(Shorearobusta),Mango(MengiferaIndica)Sisau(Dalbergiasisoo)Chap(Micheliachampa ka),Simal(BombaxMalabaricum),Okhar(JuglansRegia),Jamun(SyzygiumCumini)Chiuri(Ba ssiaButyracca), Kadam(Neolamarckia Cadamba) including many other local species including bamboo and Maluko(PisoniaExcelsa) in the hill region. In the study area, for the forest protection, a village level forest management committee has been established. Some strict rules and regulations also have been formulated and implemented.The utilization pattern of forest products, role of forest resource in local subsistence economy is discussed as follows.

\section{Firewood}

For the rural people of Nepal firewood is the principal source of energy for cooking and heating until now days. Tiwari (1980) argues that firewood is the main traditional source in Nepal for heating and cooking. In the rural areas of Nepal, firewood alone provides 95\% of all energy consumption of the country. Malla et.al (1981) also emphasizes that the forest of Nepal has been providing 95\% of firewood in rural area and $87 \%$ of the total energy consumption. In the hilly region of Nepal both male and female collect firewood from the forest to meet their basic need by cutting branches of dead and green trees. According to Steven (1993), the Sherpas of the Khumbu region use half a load of firewood perday. Likewise, Upadhyay (1993) estimated that about $540 \mathrm{~kg}$. of dry wood is needed per person per year for cooking and heating especially in the rural areas. But, use of firewood in small size household is significantly lesser than that of larger households (Fox, 1993). Wallace (1988) and Bajracharya (1983) both argue that among the traditional sources of energy, firewood consumption is higher in the villages of Nepal. In this sense, firewood is the most important fuel wood for most of the rural people in Nepal. 
Previously, in the study area, there is no any other source of energy such as solar power, cooking gas and biogas etc. so that all people have to depend on firewood for cooking. But now days few people use biogas and limited people use cooking gas as alternative energy for daily requirements. Like the other rural areas of the country, people of Sewar Bansbot also depend on firewood for daily cooking and heating because of the lack of other alternative source of energy. It shows that the local forest product is most fundamental source to meet the demand of fuel for the daily life of the people of Bansbot. They use dried or dead trees and residues for firewood instead of cutting growing and green trees. The ratio of monthly consumption of firewood for the different purposes is given in the following table.

\section{Table 1. Firewood consumption pattern of the study area}

\begin{tabular}{|l|l|l|l|l|}
\hline $\begin{array}{l}\text { Caste / ethnic } \\
\text { group }\end{array}$ & $\begin{array}{l}\text { No. of } \\
\text { household }\end{array}$ & $\begin{array}{l}\text { Average } \\
\text { family size }\end{array}$ & $\begin{array}{l}\text { Average no } \\
\text { of cattle }\end{array}$ & $\begin{array}{l}\text { Required quantity of } \\
\text { firewood } \\
\text { (inbhari) per month }\end{array}$ \\
\hline Bramhan & 5 & 4 & -- & $5-7$ \\
\hline Kshetri & 21 & 5 & 4 & $8-10$ \\
\hline Magar & 19 & 8 & 8 & $10-12$ \\
\hline Tharu & 35 & 10 & 8 & $13-15$ \\
\hline Kami & 5 & 5 & 2 & $6-8$ \\
\hline
\end{tabular}

Source: Fieldwork 2017.

Above table shows that the ratio of household consumption of firewood per month. According to table Tharu and Magar people consume more firewood than other community. It is because Tharu and Magar population is high in the study area. Other reason behind this is the family size of Tharu and Magar people is comparatively larger (see in table 1). Excluding that another reason is that they are regular liquor-consuming group. So, they use firewood for making liquor except cooking and heating food. In the season of festivals they need sufficient amount of firewood. Kami people consume lower quantity than other caste group. Similarly Kshetri and Brahman people consume only 8-10 and 5-7 Bhari of firewood respectively.

The consumption of firewood depends on the size of family member and utilization purpose. Because large family needs more firewood for cooking so they have to need more than the small family. But some families also needmore firewoodfor making Jaad (locally made alcohol) and local Raksi (locally fermented alcohol). Likewise, number of animals also 
affects and varies of firewood because people feed them 'Kudo' and 'Khole' in winter season.

Those people who have trees on their own land collect firewood from those trees during the winter. Those who have not trees on their own land, depends on public forest. Some people who can afford money for buying firewood from other people fulfill the needs during the rainy season. They useJhikra (dry twigs), Thota(inner part of dry corn), Nal(dry stalks of maize) other agricultural residues and dry twigs for the firewood purpose.Tharu people use Guitha(dry dungcake) also for cooking purpose.Some people consume firewood economically because some women expressed that they have realized the importance of firewood. In addition to this, consumption of firewood depends on its quality. If the firewood is from matured trees its consumption is less than a bundle of small low quality Jhikra (twigs). The female respondents expressed that it is very difficult to collect forest products except dry leaves. The indiscriminate cutting of small trees and immature forest products caused deforestation and led to a very difficult situation for the collection of forest products.

Respondents reported that both male and female are involved in firewood collection task from the forest. Respondents expressed that male members cut down the trees with axe and female cut and carry the wood to the desired place. Private tree owners hire laborers to do so. But those who do not have trees in private land have to depend on the public forest. Usually female collects dry firewood. The women of the study area clarified that males help them only in the time of maternity and illness period. On the occasion of festivals when more firewood is needed, male help a bit to collect forest products. Some males of the study area told that women are overloaded with domestic works. It is also noted that collecting dried forest products including firewood has been the total responsibility of women.

Respondents mentioned that people collect the firewood in the month of NovemberFebruary from the public and private forest. Those who have private forest, they cut their green trees and branches of dead trees as per their needs. And they make Khaliyo(heap) of firewood outside or inside the home. Those who do not have private forest buy green or dry trees and cut them for firewood. Hence, respondents reported that male respondents cuts trees and women carry firewood. Sal, Sisau, Chap, Chiuri, Okhar, Jamuno,Dabdabe, Dhairo, Jingatis the common species for firewood and other species of trees also collected for firewood. 


\section{Fodder}

Fodder is very important for livestock raising. Animal husbandry is common among the respondents and the nutrition for them is fodder. Animal husbandry is the main occupation and an integral part of the agro-based economy of Nepal and study area too. Macferlane (1976) assumed that forest fodder is very important source to feed cattle virtually in all the hilly regions of Nepal. Likewise, Upadhyay (1993) observed more than $40 \%$ fodder in the forest consume by the livestock.In the study area, almostall households collect fodder, grass and dry straw to feed the animals from the forest and their private land. For the purpose of milk production, manure for crop field, and oxen for ploughing people domesticate a small number of animal populations only for household use.

Leaves, green twigs and small plants are needed for livestock as their diet. Where the practice is overdone, whole branches will be amputated and the trees will consequently be considerably weakened (Reiger, 1976). Similarly Gurung (1988) also pointed out that fodder is also used to produce manure for agricultural production in rural area. Women are directly related with animals and fodder. Women normally collect fodder. In the study area, it is observed that most of the people collect fodder from their own private land. Those people, who don't have their own private land for fodder, are fully depending on public or community forest. So nearby forest and private land are sources of fodder. But some people buy the fodder from others land. People who have fodder in their lands reserve the land and prefer to cut from public land till they are easily available. Thus they are more conscious to protect their personal fodders of their own land than public forest. In response to fodder collection, key informant opined that males cut branches of fodder especially from big trees. Since the month of Jestha- Kartik, they collect the green grass from their own land and forest. During the dry season they feed their cattle with hay, straw, maize stalks and other dried fodder. Little amount of green fodder is harvested from the agricultural. Buffalo, cow, ox, goat and pig are commonly domesticated for purpose of milk, ploughing and manure. The consumption pattern of fodder is shown in the following table

Table 2. Sources and seasonal fodder consumption pattern

\begin{tabular}{|l|l|l|}
\hline \multirow{2}{*}{ Source of fodder } & \multicolumn{2}{|l|}{ Per day average fodder consumption in (bhari) } \\
\cline { 2 - 3 } & Summer & Winter \\
\hline Pakho/ kharkatti & 100 & 10 \\
Agricultural field & 120 & 40 \\
Community forest & 35 & -- \\
Others & 10 & 16 \\
\hline Total & 265 & 66 \\
\hline
\end{tabular}


Source: Fieldwork 2017.

According to above table and respondents, 265-bhari grasses are used in summer per day. In rainy season green grass is available in their agricultural land. Only from agricultural field 120 Bhari grass is consumed per day. Similarly in winter season only 66 Bhari grass is consumed per day because green grass is not easily available in winter season. In the winter season, they feed hay, straw, dried grass and other agricultural residues. The second source of fodder is Pakho/Kharkatti. Because of unavailability of grasses only 100Bharifodder is used in summer, and 10 Bhari grass in winter is collected from Kharkattiper day. But those who do not have private land they buy from others. Community forest is only opened in summer for some days to cut grass at that time people collect 35Bhari(unit of fodder approximately) of fodder per day.

\section{Consumption of animal bedding}

Green animal bedding is called Sotar in local language. The importance of Sotar (green animal bedding) is great in the study area. Green leaves small branches are used as animal bedding for manufacturing compost manure for agriculture. Forest, public hills and private land have been supplying the Sotar for the people of the study area. The main source of Sotaris private land and nearby bushy hills. Local people in the study area consume Sotarin order to obtain high volume of compost manure. During the rainy season, local people utilize bedding materials regularly however it is irregular in winter season because of its unavailability. Some people deposit green leaves into the compost pitfor de-composition, which is converted into the organic manure. And farmers use this manure in their crop fields according to the requirements. The organic manure prepared by Sotar has been played a vital role in the rural areas where people are poor and cannot afford for chemical fertilizer. It helps to preserve and improve the soil quality. It is considered as substitute of animal manure.

According to the field study Sotar (green leaf litter) for animal bedding is used specially in rainy season. Consumption of animal bedding is not uniform among all the respondents. It is mainly depend on the livestock size and availability of the bedding materials in the surroundings. Almost all respondents collect animal bedding from private land and common bushy hills. Besides this, the remaining portion of the animal supply grass, fodder also used as Sotarin both rainy and winter season. In winter season dry leaves, straw are used as animal bedding. The livestock size usually determines the consumption of animal bedding. 


\section{Forest as common grazing land}

Cattle are strictly prohibited in the entire area of ban to graze. If anyone ignores the rules and allows cattle for grazing, will be fined by management committee and fine will be deposited in the treasury. Lack of pastureland and fodder they cannot domesticate larger number of livestock. The domesticated animals never graze in the common grazing field or in the forest. They are kept at home which is called Badhuwa, by providing relatively qualitatively feeding materials to them. Likewise, timber for the private purpose also strictly prohibited. According to key informants those people who are suffered by natural disaster allowed acquiring timber according to the committee's decision that would be free of charge.

\section{Conclusion}

The utilization pattern of different forest products varies according to the ecological regions for fuel and fodder. Studies have been conducted in different parts of Nepal about forest management but studies have hardly been made on the forest utilization pattern. Like the other rural areas of the country, people of Sewar Bansbot also depend on firewood for daily cooking and other domestic use because of the lack of other alternative source of energy.In the study area, it is observed that most of the people collect fodder from their own private land. Those people, who don't have their own private land for fodder,fully depend on community forest. Despite of studies and program formulations destruction of forest has not been obsolete due to lack of availability and access to other alternative sources and awareness.

\section{References}

Bajracharya, Deepak. (1983). Deforestation in the Food/Fuel Context, Historical and Political Perspective from Nepal. Mountain Research and Development 3 (3): 227-240.

Bhatia, A. (1999). Participatory Forest Management: Implications for Policy and Human Resources Development in the Hindu-Kush Himalayas, Vol.V, ICIMOD, Nepal.

Fox, Jefferson. (1993). Forest Resource in a Nepali Village in 1980 \& 1990: the Positive Influence of Population Growth. Mountain Research and Development. England: University of California Press.

Gilmour, D. A., and R. J. Fisher. (1991). Village, Forests and Foresters: the Philosophy, process and Practice of Community Forestry in Nepal. SahayogiPress Kathmandu.

Gurung, G.M. (1988). People's Participation in Forest Development.Master Degree Thesis, Submitted to T.U., Kirtipur, Kathmandu.

HMG. (1994). Economic Survey. Kathmandu: Ministry of Finance. 
Macfarlane, A.(1976). Resource and Population: A Study of Gurung of Nepal. London: Cambridge University Press.

Malla, K.B., and T.B. Mahat. (1981). Forest Resources. Bista,Nirmal Kumar (ed). Development of the Himalayan Resourcesfor National Development. CEDA. Kathmandu.

Regmi, S.C. (1992). Women in Forestry: Study of Women's Forest Committee in a Nepalese Village. Kathmandu: Ministry of Agricultural andWinrock International.

Reiger, H.V., Bieri, F., Eggers, H., Goldschalt, W. and Steiger. J.(1976).Himalayan Ecosystems Research Mission: Nepal Report. Heidelberg.

Sharma, N.P. (1992). Managing the World's Forests: Kendall/Hunt Publishing Company

Steven, Stanley F. (1993).Claiming the High Ground: Sherpas' Subsistence and Environmental Change in the Highest Himalaya. England: university of California Press.

Tiwari, R.N. (1980). Community Forestry Management for Rural Development.India.

Upadhyay, K.D. (1993). Forestry and farming in the Hills of Nepal: Occasional Paper in Sociology and Anthropology 3, pp.3-9.

Wallace, M.B. (1988). Forest Degradation in Nepal: Institutional Context and Policy Alternatives. Research Report Series no.6, Winrock International, Kathmandu. 